\title{
Tropidia rostrata (Diptera, Syrphidae), First Recorded Genus and Species in Korea
}

\author{
Sang-Wook Suk, Ho-Yeon Han* \\ Division of Biological Science and Technology, Yonsei University, Wonju 220-710, Korea
}

\begin{abstract}
We discovered a syrphid species, Tropidia rostrata Shiraki, 1930, for the first time in Korea. This is the first member of the genus Tropidia recorded in Korea. This species can be distinguished from other Palaearctic members of Tropidia by the combination of the following characteristics: lower facial margin strongly protrudes forward; apical 3/4 of hind femur black; and tergites 2 and 3 each with a pair large yellowish brown square spots (not reached hind margin). We here provide a detailed redescription supplemented by the color photographs of external structures including genitalia. We also discussed the status of primary types associated with this taxon.
\end{abstract}

Keywords: Diptera, Syrphidae, taxonomy, Tropidia rostrata, Korea

\section{NTRODUCTI ON}

The genus Tropidia was erected by Meigen (1822) based on the type species, Tropidia scita (Harris, 1780) (as Eristalis milesiformis Fallen, 1817; junior synonym). This genus currently includes 22 valid species from all zoogeographical regions as of February, 2014 (The Diptera Site; http://www. diptera.org/). They can be distinguished from other Palaearctic syrphid taxa by the combination of the following characteristics provided by Thompson and Rotheray (1998) and Vockeroth and Thompson (1987): 1) arista bare; 2) cell $\mathrm{r}_{1}$ open to wing margin; 3) crossvein $\mathrm{dm}-\mathrm{cu}$ and apical crossvein nearly continuous each other; and 4) hind femur swollen with large subapical ventral triangular process.

Based on a series of specimens recently collected in southern part of South Korea (Pohang-si), we here report Tropidia rostrata for the first time in Korea. This is the first member of this genus recorded in Korea. We here provide a detailed redescription supplemented by the color photographs of external structures including genitalia.

\section{MATERI ALS AND METHODS}

The morphological terminology and interpretations follow McAlpine (1981) and Thompson (1999). The two lengths and five ratios used in the descriptions were modified from Han and Norrbom (2005): body length (anterior margin of head excluding antenna to posterior margin of abdomen); wing length (anterior margin of tegular to apex of vein $\mathrm{R}_{4+5}$ ); facehead ratio (width of face/width of head in dorsal view); eye ratio (shortest eye diameter/longest eye diameter); wing-mesonotum ratio (wing length/mesonotum length); vein $\mathrm{R}_{4+5}$ ratio (distance along vein $R_{4+5}$ between crossvein $r-m$ and vein $R_{4+5}$ apex/distance between crossvein $r-m$ and basal node of vein $\mathrm{R}_{4+5}$ ); and vein $\mathrm{M}$ ratio (distance along vein $\mathrm{M}$ between crossveins $\mathrm{r}-\mathrm{m}$ and $\mathrm{dm}-\mathrm{cu} /$ distance between crossveins $\mathrm{r}-\mathrm{m}$ and bm-cu).

All the examined Korean specimens are deposited in the Division of Biological Science and Technology, Yonsei University, Wonju Campus, Korea (YSUW). We also examined some Japanese specimens including the holotype of Parrhyngia quadrimaculata Shiraki (junior synonym of T. rostrata) in National Institute for Agro-Environmental Science, 3-1-3 Kannondai, Tsukuba, 305-8604, Japan (NIAES).

\section{SYSTEMATI C ACCOUNTS}

Order Diptera

Family Syrphidae Latreille, 1802

Genus Tropidia Meigen, 1822 (c) This is an Open Access article distributed under the terms of the Creative Commons Attribution Non-Commercial License (http://creativecommons.org/ licenses/by-nc/3.0/) which permits unrestricted non-commercial use, distribution, and reproduction in any medium, provided the original work is properly cited.

pISSN 2234-6953 eISSN 2234-8190
*To whom correspondence should be addressed

Tel: 82-33-760-2254, Fax: 82-33-760-2183

E-mail: hyhan@yonsei.ac.kr 
${ }^{1 *}$ Tropidia rostrata Shiraki, 1930 (Figs. 1, 2)

Tropidia rostrata Shiraki, 1930: 90 (holotype 우: Japan, Hokkaido, Sapporo, VII [NIAES], examined).

Rhinotropidia rostrata: Stackelberg, 1930: 227 (type species of new genus Rhinotropidia Stackelberg); Shiraki, 1968: 53 (redescription); Violovitsh, 1983: 131 (in Siberian key); Peck, 1988: 62 (in Palaearctic catalog); Mutin and Barkalov, 1999: 484 (in Russian Far East key).

Parrhyngia quadrimaculata Shiraki, 1968: 205 (holotype ơ': Japan, Kyoto, Koga, 23 Sep 1936, T. Kimura [NIAES], examined); Peck, 1988: 62 (in synonymy of Rhinotropidia rostrata).

Material examined. Korea: Chungcheongnam-do: $10^{7}$, Taean-gun, Sowol-myeon, Cheollipo Arboretum, $36^{\circ} 47^{\prime} 55^{\prime \prime} \mathrm{N}$, $126^{\circ} 08^{\prime} 59^{\prime \prime} \mathrm{E}, 14$ Jun 2007, Choi DS; Gyeongsangbuk-do: $380^{7} \sigma^{7}, 18$ 우 우, Pohang-si, Buk-gu, Heunghae-eup, Gokgang-ri, $36^{\circ} 06^{\prime} 51^{\prime \prime} \mathrm{N}, 129^{\circ} 23^{\prime} 37^{\prime \prime} \mathrm{E}$, alt. $32 \mathrm{~m}, 4$ Jun 2011 , Suk SW et al.; Japan: holotype 우 of Tropidia rostrata Shiraki and holotype ${ }^{7}$ of Parrhyngia quadrimaculata Shiraki in NIAES (see type data in the synonymy).

Diagnosis. This species can be distinguished from other Palaearctic members of the Tropidia by the combination of the following characteristics: 1) lower facial margin strongly protrudes forward (Fig. 1B, D); 2) apical 3/4 of hind femur black (Fig. 1B, D, G); and 3) tergites 2 and 3 each with a pair large yellowish brown square spots (not reached hind margin) (Fig. 1A, C). Sexual dimorphism of the shape and color pattern of abdomen is observed (Fig. 1A vs. C).

Redescription of male. Body length $9.5-11.3 \mathrm{~mm}$; wing length 5.6-7 mm. Head (Fig. 1A, B, E) with face-head ratio $0.37-0.39$; eye ratio $0.64-0.68$; vertex brownish black with yellowish brown pruinosity posterolaterally, with yellowish brown hairs; ocellar triangle brownish black with yellowish brown hairs; ocelli arranged in isosceles triangle; occiput brownish black with pale yellow pruinosity densely, with yellowish brown and some brownish black hairs mixed; frons with heavy yellowish brown pruinosity except for shiny dark brown lower median portion; lower facial margin strongly protrudes forward; frons with heavy yellowish brown pruinos-
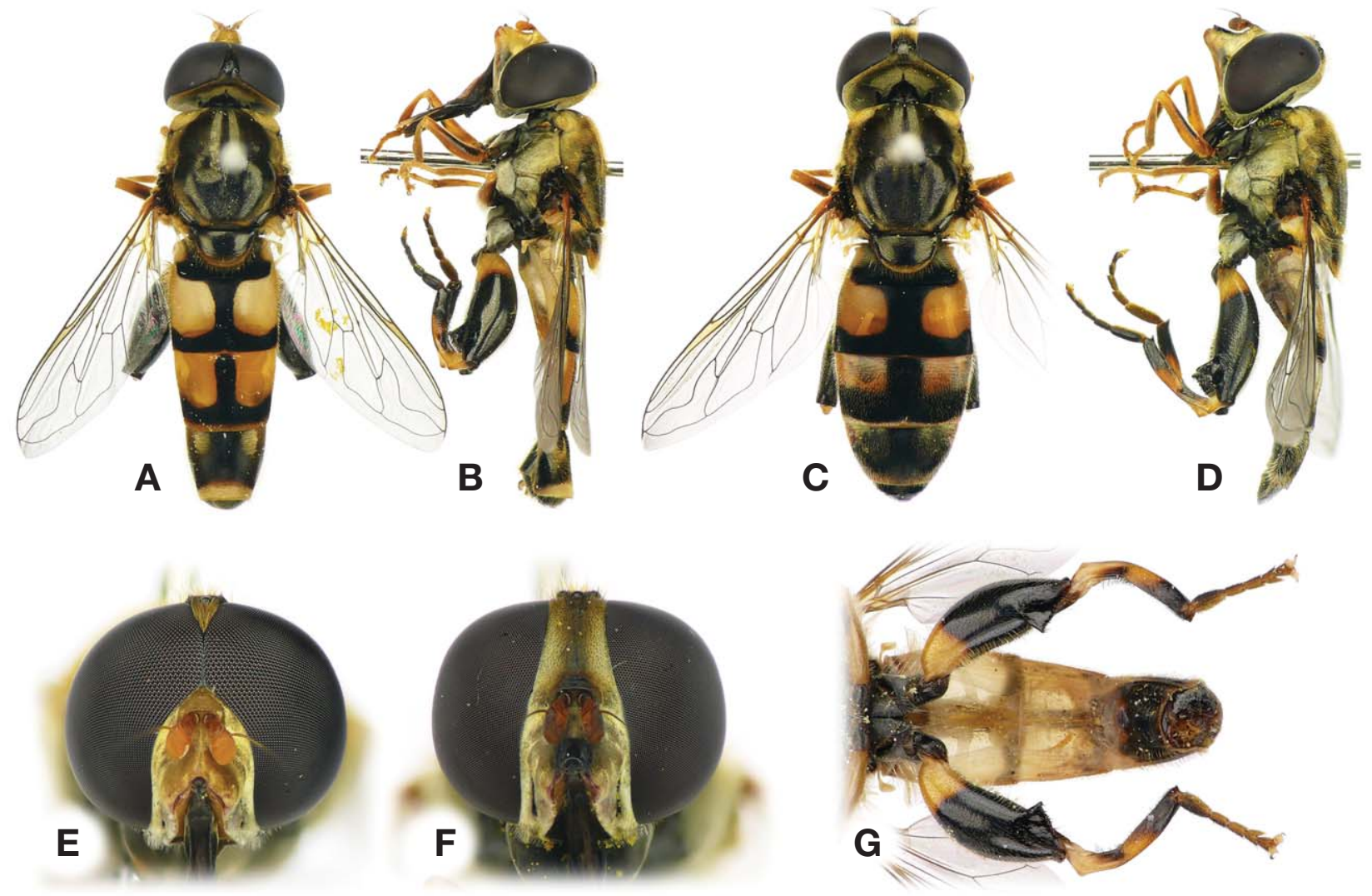

Fig. 1. Tropidia rostrata. A, B, E, G, Male (11.2 mm excluding antennae); C, D, F, Female (11.3 mm).

Korean name: ${ }^{1 *}$ 가시꽃등에 (신칭) 

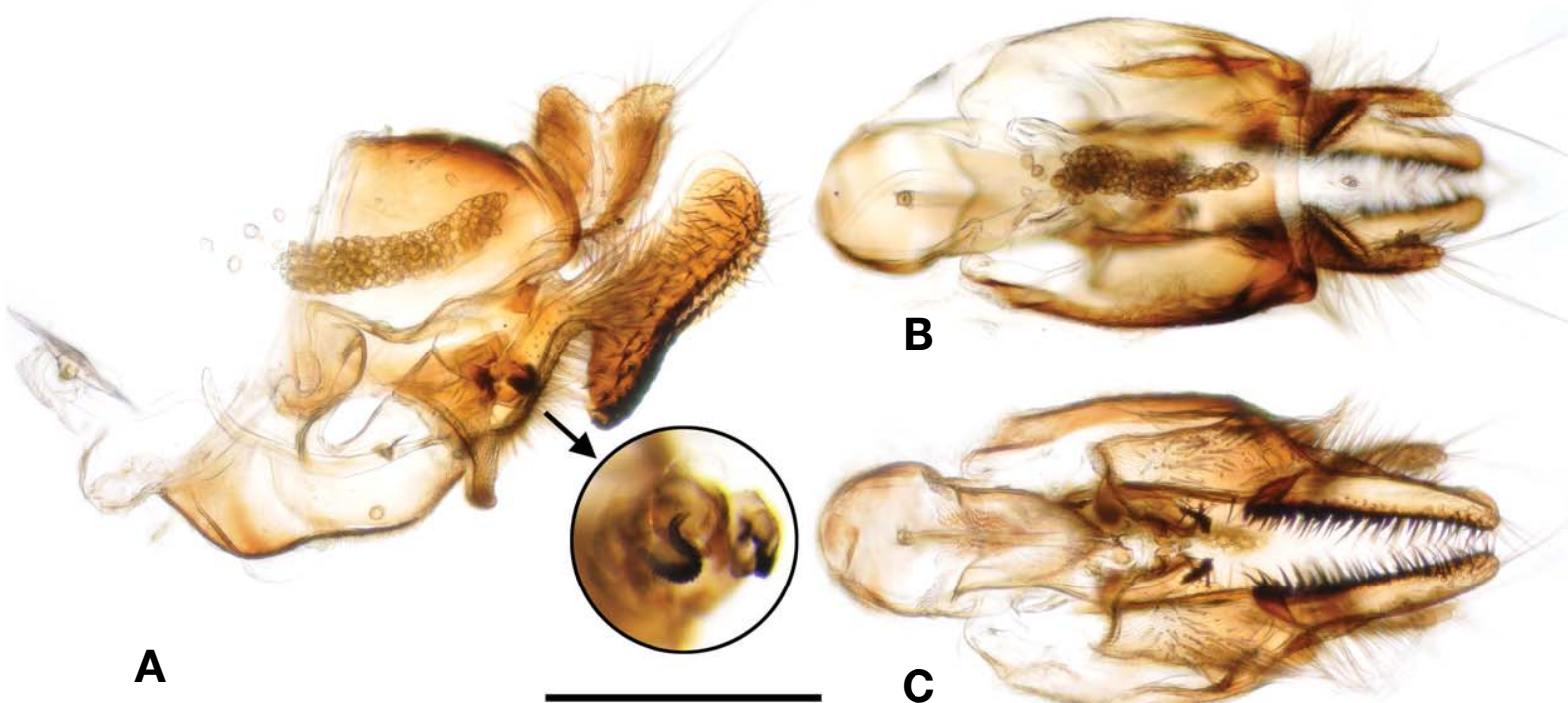

B

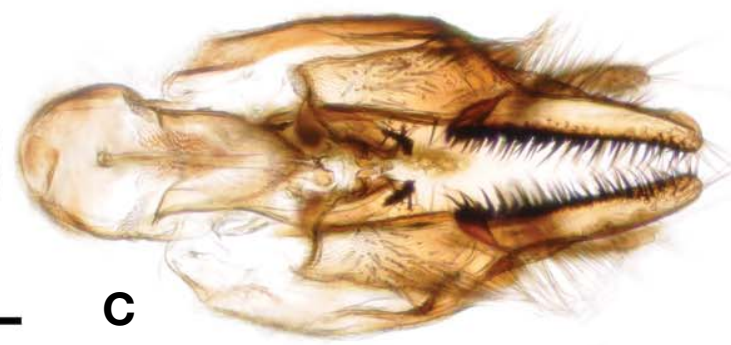

Fig. 2. Tropidia rostrata, male genitalia. A, Lateral view; B, Dorsal view; C, Ventral view. Scale bar=0.5 mm.

ity except for dark brown lower median portion and narrow mid-line upward; gena brownish black with pale yellow hairs; parafacial with yellow microscopic hairs; eyes holoptic, bare; antennal scape and pedicel yellowish brown with brownish black hairs dorsally; flagellomere 1 yellowish brown, bare; arista yellowish brown to dark brown, bare. Thorax (Fig. 1A, B) predominantly brownish black with yellowish brown hairs, with pale yellow pruinosity; scutum shiny black with pale yellow pruinosity laterally except on middle area, anterior $2 / 3$ of scutum with pair of pale yellow submesal longitudinal stripes; notopleuron and postalar callus densely with pale yellow pruinosity; scutellum shiny brownish black in ground color with yellowish brown posteromarginally; postpronotum with pale yellow pruinosity, with lateral $1 / 3$ yellowish brown hairs; anterior anepisternum with grayish pruinosity, bare; posterior anepisternum with grayish pruinosity except for ventral 1/3 area; proepimeron brownish black with grayish pruinosity, bare; katepisternum with large longitudinally elliptic grayish pruinosity dorsally, mostly bare except for yellow hairs on grayish pruinosity; anepimeron and katepimeron with grayish pruinosity; meron with grayish pruinosity, bare; katatergite posteriorly with yellowish brown hairs. Wing (Fig. 1A) entirely microtrichose, mostly hyaline except for pterostigma yellowish brown; cell $r_{1}$ open to wing margin; crossvein $\mathrm{dm}-\mathrm{cu}$ and apical crossvein nearly continuous each other; wing-mesonotum ratio 1.71-1.91; vein $\mathrm{R}_{4+5}$ ratio 1.54-2; vein $\mathrm{M}$ ratio $0.63-0.8$; calypter pale yellow, marginally with yellowish brown hairs; halter yellow. Legs (Fig. 1B, G) predominantly yellowish brown in ground color with some darker areas, with yellowish brown hairs; fore coxa brown- ish black, posteriorly bare; fore trochanter brownish black (some individuals have brownish black hairs apically); fore femur dorsally with brownish black longitudinal stripe except for basal and apical areas, ventrally with similar stripe at apical $1 / 2$; apical $1 / 4$ of fore tibia brownish black; fore tarsus with some brownish black hairs apically; mid coxa brownish black, anteriorly with long yellowish brown hairs, posteriorly bare; midfemur both dorsally and ventrally with brownish black longitudinal stripes at apical 1/2; midtarsus with some brownish black hairs apically; hind coxa brownish black with pale yellow pruinosity, posteriorly bare; hind trochanter brownish black (some individual brownish black hairs mixed); apical 3/4 of hind femur brownish black, swollen with large subapical ventral triangular process (this process covered with brownish black spine-like hairs posteriorly); hind tibia strongly curved dorsally at basal $1 / 3$, with subbasal dorsal tubercle, with apex ventrally pointed, yellowish brown with apical 1/3 entirely brownish black, with brownish black ventral spot at basal 1/3, also with brownish black hairs ventrally; hind tarsus brownish black dorsally, yellowish brown ventrally. Abdomen (Fig. 1A, B, G) conical shape with preabdominal tergites brownish black in ground color with brownish yellow spots laterally, with brownish black hairs except on yellowish brown areas yellowish brown hairs; tergite 1 entirely brownish black with brownish black hairs posteromarginally; tergite 2 with pair of elongated square yellowish brown spots (about $4 / 5$ as long as tergite length); tergite 3 with elongated square spots (slightly fused anteriorly; about $4 / 5$ as long as tergite length) and with narrow brownish yellow posteromarginal band; tergite 4 predominantly brownish 
black with small triangular yellowish brown spot anterolaterally; also with round grayish sublateral pruinose spots right next to yellow spots; sternites 1, 4, 5 brownish black, and sternites 2-3 brown; all preabdominal sternites covered with yellowish brown hairs. Genitalia (Fig. 2A-C; coloration faded due to $\mathrm{KOH}$ treatment) nearly dark brown; epandrium rounded dorsally in lateral view with brown hairs; cercus more or less reverse triangular in lateral view with transverse constriction; in lateral view, sustylus constricted medially and widened greatly apically; sustylus with long dense hairs basally and shorter and recumbent hairs apically; superior lobe (sensu Thompson, 1999) S-shaped with regular transvers serrations, strongly sclerotized; aedeagus simple tube shape, concealed by superior lobes.

Female. Similar to male except for the following non-genitalic characters (Fig. 1C, D, F): frons and face with brownish black transverse mid-stripe; eyes dichoptic. Abdomen narrowly oval shape; tergite 2 and 3 similar to those of males but dark area $1.5-2 \times$ as wide; tergite 4 with similar antero-lateral triangular yellowish brown spots but grayish pruinosity spots covering almost twice as long and wide areas; tergite 5 dark brown, barely seen in dorsal view. Lengths and ratios: body length $9.2-10.5 \mathrm{~mm}$; wing length $5.5-7.1 \mathrm{~mm}$; facehead ratio 0.29-0.37; eye ratio 0.59-0.75; wing-mesonotum ratio 1.77-1.89; vein $R_{4+5}$ ratio $1.64-1.82$; vein $M$ ratio 0.64 -0.86 .

Distribution. Korea, Japan, Russian Far East, China.

Remarks. Shiraki (1930) originally described this species based on the single holotype female, but Shiraki (1968) somehow erected a new genus and species, Parrhyngia quadrimaculata, based on four conspecific specimens (holotype male and three paratype females). This nominal species was synonymized accordingly by Peck (1988). We examined the both holotypes in NIAES and confirmed this synonymy. This species is very rare in Korea but over fifty specimens were collected in June 4, 2011 in Pohang-si (see Material examined). Most specimens were swept from flowers of Erigeron annuus (Linnaeus) Persoon at a small spot in a rural lowland area.

\section{ACKNOWLEDGMENTS}

We are grateful to Shin-ichi Yoshimatsu (NIAES) for making the holotypes of Tropidia rostrata and Parrhyngia quadrimaculata available to us when we visited NIAES in 2011. We also thank Deuk-Soo Choi, Yong-Bong Lee, Hak-Seon Lee, and Dong-Han Kim for collecting the Korean Tropidia specimens used in this study. This research was supported by the Korean Ministry of Environment (the Project on the Survey of Indigenous Biological Resources of Korea, NIBR).

\section{REFERENCES}

Fallen CF, 1816-1817. Syrphici Sveciae. Berlingianis, Lundae [=Lund], pp. 1-22 [1816], 23-62 [1817].

Han HY, Norrbom AL, 2005. A systematic revision of the New World species of Trypeta Meigen (Diptera: Tephritidae). Systematic Entomology, 30:208-247.

Harris M, 1776-1780. An exposition of English insects: with curious observations and remarks, wherein each insect is particularly described; its parts and properties considered; the different sexes distinguished, and the natural history faithfully related. Robson Company, London, Decad I, pp. 140 [1776]; Decad II, pp. 41-72 [1778]; Decads III, IV, pp. 73-99, 100-138 [after 1779]; Decad V, pp. 139-166 [1780].

Latreille PA, 1802. Histoire Naturelle, générale et particuliére des crustacés et des insectes. Tome troisiéme. Familles naturelles et genres. F. Dufart, Paris, pp. 13-467.

McAlpine JF, 1981. Morphology and terminology: adult. In: Manual of nearctic diptera. Vol. 1 (Eds., McAlpine JF, Peterson BV, Shewell GE, Teskey HJ, Vockeroth JR, Wood DM). Research Branch, Agriculture Canada, Ottawa, ON, pp. 963.

Meigen JW, 1822. Systematische Beschreibung der bekannten europaischen zweiflugeligen Insekten. Dritter Theil, SchulzWundermann, Hamm, pp. 1-416.

Mutin VA, Barkalov AV, 1999. Family Syrphidae. In: Key to the insects of Russian Far East. Vol. 6. Diptera and Siphonaptera. Pt 1 (Ed., Lehr PA). Dal'nauka Publisher, Vladivostok, pp. 342-500 (in Russian).

Peck LV, 1988. Family Syrphidae. In: Catalogue of palaearctic diptera. Vol. 8 (Eds., Soós Á, Papp L). Elsevier Science, Amsterdam and Akadémiai Kiadó, Budapest, pp. 11-230.

Shiraki T, 1930. Die Syrphiden des Japanischen Kaiserreichs, mit Berucksichtigung benachbarter Gebiete. Memoirs of the Faculty of Science and Agriculture, Taihoku Imperial University, 1:1-446 (in German).

Shiraki T, 1968. Fauna Japonica, Syrphidae (Insecta). Vol. III. Biogeographical Society of Japan, Tokyo, pp. 1-272.

Stackelberg AA, 1930. Beiträge zur Kenntnis der palaearktischen Syrphidae. III. Konowia, 9:223-234.

Thompson FC, 1999. A key to the genera of the flower flies (Diptera: Syrphidae) of the neotropical region including descriptions of new genera and species and a glossary of taxonomic terms. Contributions on Entomology, International, 3:321-378.

Thompson FC, Rotheray G, 1998. Family Syrphidae. In: Contributions to a manual of palaearctic diptera (with special reference to flies of economic importance). Vol. 3. Higher Brachycera (Eds., Papp L, Darvas B). Science Herald, Budapest, pp. 81-139.

Violovitsh NA, 1983. Siberian Syrphidae (Diptera), pp. 1-241 (in Russian). Translation to English (1986). Instituut voor Taxonomische Zöologie, Zöologische Museum, Amsterdam, pp. 1-228.

Vockeroth JR, Thompson FC, 1987. Family Syrphidae. In: Man- 
ual of nearctic diptera. Vol. 2 (Eds., McAlpine JF, Peterson BV, Shewell GE, Teskey HJ, Vockeroth JR, Wood DM). Research Branch, Agriculture Canada, Ottawa, ON, pp. 713776.
Received March 11, 2014 Revised May 18, 2014 Accepted J une 26, 2014 